\title{
Komunikasi Efektif pada Anak Usia Dini dalam Pengenalan Ajaran Agama Hindu
}

\author{
Anggara Putu Dharma Putra ${ }^{1}$, Dewa Putu Tagel ${ }^{2}$ \\ Fakultas Dharma Duta \\ Institut Hindu Dharma Negeri Denpasar
}

\begin{abstract}
The process of communication can occur anywhere such as home, office, hospital, and school. Effective communication is the flow of information or messages in two directions between the communicator and the communicant as well as the information is equally addressed in accordance with the expectations of both actors (communicator and communicant). From the description above, the writer wants to conduct research on "Effective Communication In Early childhood In the Introduction of the Hindu Religion". Based on the description of the background din above, the writer can formulate the following problem formulation: 1) How personal communication in the introduction of the teachings of Hinduism? 2) How Effective Communication In Early Childhood In The Introduction Of The Teachings Of Hinduism? 3) How the impact of Effective Communication caused in early childhood in the introduction of the Teachings of the Teachings of Hinduism?

To dissect the problems in this study used 3 kinds of theories, namely 1) the Theory of interaction patterns of the relationship to determine the personal communication in the introduction of the teachings of Hinduism, 2) Theory of Effective Communication to determine the effectiveness of communication in early childhood in the introduction of the teachings of the Hindu Religion, 3) the Theory of Expectation Value to determine the impact of the introduction of the teachings of Hinduism in early childhood.

After getting the accurate data, followed by analyzing the data obtained using the technique of data analysis, inter-personal communication is a form of communication between teachers and students, students with fellow students, teachers with parents of students as well as students with parents that happens to the equation of perception in penyemapian knowledge. Effective communication gives an overview of the objectives and results to be achieved by the school maupaun teaching teachers in the classroom Impact the internal is the ability to understand
\end{abstract}

\footnotetext{
1 angga.lecturer007@gmail.com

2 dewa_tagel@ihdn.ac.id
} 
themselves and responsible for his own life. External impact is the result of the processing of the knowledge process in each individual that arises through the action.

Keywords

inter-personal Communication; The Role of Effective Communication; The Impact of Effective Communication

\section{PENDAHULUAN}

Usia dini merupakan usia keemasan untuk mendapaTaman KanakKanakan suatu pengetahuan, keterampilan dan nilai-nilai moral yang nantinya akan dapat membentuk karakter bagi anak usia dini sendiri. Dalam hal ini pemerintah ikut serta membantu masyarakat dengan mengeluarkan peraturan pemerintah No. 27/1990 tentang pendidikan Prasekolah yang menyatakan:“Pendidikan prasekolah adalah pendidikan untuk membantu pertumbuhan dan perkembangan jasmani dan rohani anak didik dilingkungan keluarga dalam memasuki pendidikan dasar yang diselenggarakan dijalur pendidikan prasekolah atau dijalur pendidikan luar sekolah" serta memberikan bantuan dengan mendirikan sekolah khusus untuk mendidik anak yang usianya masih prasekolah yaitu Taman Kanak-Kanak.

Ajaran-ajaran Agama Hindu di Taman Kanak-Kanak disampaikan melalui komunikasi yang efektif dan sederhana, baik itu dengan komunikasi verbal maupun nonverbal. Komunikasi efektif adalah aliran informasi atau pesan dua arah antara komunikator dan komunikan serta informasi tersebut sama-sama direspon sesuai dengan harapan kedua pelaku (komunikator dan komunikan). Penyampaian tentang pengenalan ajaran Agama Hindu sebagai suatu bentuk komunikasi antara guru dan murid di kelas. Di Taman KanakKanak penyampaian pelajaran menggunakan bahasa yang sederhana yang mudah dimengerti oleh murid dan menggunakan beberapa metode seperti, metode diskusi, tanyajawab dan demontrasi.

Interaksi sosial merupakan proses orang-orang berkomunikasi yang dapat saling mempengaruhi dalam pikiran dan tindakan. Interaksi juga diartikan hubungan sosial yang dinamis menyangkut hubungan antara orang perorangan, antara kelompok-kelompok manusia maupun antara orang perorangan dengan kelompok manusia.

Pengalaman anak-anak di Taman Kanak-Kanak merupakan jembatan antara rumah dan sekolah. Taman Kanak-Kanak mengemban misi untuk menciptakan pengalaman antara dunia anak -anak dalam keluarga dengan tuntutan kehidupan dan tututan belajar di jenjang pendidikan selanjutnya. Dasardasar keterampilan, pengetahuan, dan sikap yang diletakkan pada pendidikan prasekolah atau usia dini termasuk pendidikan yang dilakukan di Taman Kanak-Kanak bukan hanya berpengaruh pada kehidupan sekolah atau sementara saja, melainkan mempengaruhi kehidupan selanjutnya dan sepanjang hayat. Pemahaman agama Hindu di Taman Kanak-Kanak juga mengandung tujuan untuk membantu perkembangan anak sejak usia dini agar dapat tumbuh dan berkembang secara wajar dan 
seimbang sebagai anak dalam aspekaspek fisik, keterampilan, pengetahuan, sikap, perilaku sosial dan pengertian tentang agama sebagai pondasi dasar dalam menjalani kehidupan selanjutnya

\section{Metode Penelitian}

Menurut Kamus Besar Bahasa Indonesia (1989 : 932) landasan Teori adalah suatu pendapat yang dikemukakan sebagai keterangan suatu peristiwa. Landasan teori dapat dikatakan suatu kebijakan dalam penelitian berdasarkan pendapat yang dikemukakan sebagai keterangan dengan data yang terkumpul. Jadi landasan teori merupakan teori-teori yang akan digunakan sebagai alat atau landasan untuk menjawab permasalahan yang akan diajukan, sehingga jawaban yang dihasilkan merupakan jawaban yang teoristis dan sistematis. Teori merupakan informasi ilmiah yang diperoleh dengan cara meningkaTaman Kanak-Kanakan abstraksi pengertianpengertian maupun hubunganhubungan pada proposisi (Triguna dkk, 1987:12). Selain itu teori juga dapat berfungsi untuk penjelasan, prediksi dan kontrol sosial. (Zamoni, 1992:4-5) serta mencapai hasil yang maksimal digunakan suatu teori sesuai dengan topik yang akan penulis bahas "Komunikasi Efektif Pada Anak usia dini Dalam Pengenalan Ajaran Agama Hindu".

Sehubungan dengan hal tersebut, maka ada beberapa teori yang digunakan oleh penulis sebagai landasan atau pedoman agar dapat mengarahkan peneliti dalam memahami persoalan yang sedang dikaji, yaitu :

1) Teori Pola Interaksi Hubungan

Gagasan yang dikemukakan Gregory Batseon dan Paul watzlawick memberikan pengaruh sangat besar dalam pemikiran mengenai hubungan dalam ilmu komunikasi khususnya pada tahun-tahun awalan berkembangnya studi mengenai komunikasi interpersonal. Kedua teoretisi ini bersama sejumlah sarjana lainnya dikenal juga dengan sebut Paolo Alto Group, karena mereka kemudian mebangun lembaga bernama Mental Research Institute di Paolo Alto, California. Tiga orang dari kelompok Paolo Altoini kemudian menuangkan gagasan mereka ke dalam buku yang saat ini sudah menjadi klasik berjudul Pragmatics of humanCommunications.

Paolo Alto menyatakan ada dua jenis pola hubungan yang penting yaitu "hubungan simetris" dan "hubungan komplementer". Hubungan simetris terjadi jika dua orang saling memberikan tanggapan dengan cara yang sama. Jika seseorang menyatakan bahwa ia yang berwenang terhadap sesuatu (memiliki kontrol), tetapi sebaliknya orang lain menyatakan ia yang memegang kontrol terhadap sesuatu maka kondisi ini merupakan hubungan simetris. Contoh hubungan simetris ini adalah dalam hal perebutan wewenang atau kekuasaan. Namun demikian hubungan simetris tidak selalu dalam bentuk perebutan kekuasaan secara terbuka tetapi dapat dilakukan dengan cara yang lebih halus, misalnya memberi respons secara pasif, atau bahkan kedua belah pihak berperilaku seolah-olah saling mendukung.

Berdasarkan teori Pola Interaksi Hubungan tersebut penulis berharap dapat menyelesaikan dan menunjang rumusan masalah yang pertama, hingga terjawab nilai yang diharapkan terhadap anak didik, sehingga jelas komunikasi antar personal yang dapat terjadi dalam 
pengenalan ajaran Agama Hindu di Taman Kanak-Kanak.

2) Teori Komunikasi Efektif

Setiap hari tanpa kita sadari kita telah melakukan komunikasi dengan orangorang disekitar kita. Karena pada dasarnya komunikasi merupakan sebuah kebutuhan dari setiap manusia yang disebut sebagai makhluk sosial. Untuk tercapainya tujuan atau harapkan dari sebuah informasi yang disampaikan oleh seseorang atau beberapa orang kepada orang lain tentunya harus terjalin sebuah komunikasi yang efektif. Menurut Widjaja (2009: 49) menyatakan bahwa komunikasi merupakan kegiatan pengirirman dan penerimaan lambang ataupun keinginan untuk mengubah pendapat orang lain yang merupakan suatu usaha untuk mengadakan hubungan sosial.

Berdasarkan teori Komunikasi Efektif tersebut penulis berharap dapat menyelesaikan dan menunjang rumusan masalah yang kedua, hingga terjawab nilai yang diharapkan terhadap anak didik, sehingga jelas efektifitas komunikasi pada anak usia dini dalam pengenalan ajaran Agama Hindu.

3) Teori Nilai Harapan

Teori Nilai Harapan ini adalah teori yang menegaskan harapan untuk mendapaTaman Kanak-Kanakan suatu nilai seperti yang diharapkan. Seperti halnya di Taman Kanak-Kanak, sejauhmana pengenalan ajaran Agama Hindu akan mempengaruhi sikap mental dan tingkahlaku anak dan seberapa banyakkah siswa yang dapat mengamalkan ajaran-ajaran yang telah disampaikan oleh guru disekolah. Jika anak lebih banyak yang mampu mengamalkan ajaran-ajaran yang disampaikan, berarti nilai harapan yang diharapkan dapat tercapai. Tetapi jika sebaliknya yang mampu mengamalkannya lebih sedikit berarti nilai harapan belum dapat tercapai dan perlu pengulangan.

Berdasarkan teori Nilai Harapan tersebut penulis berharap dapat menyelesaikan dan menunjang rumusan masalah yang ke tiga, hingga terjawab nilai yang diharapkan terhadap anak didik. Sehingga jelas dampak yang ditimbulkan dalam pengenalan ajaran Agama Hindu.

\section{PEMBAHASAN}

\section{Komunikasi Antar Personal dalam pengenalan ajaran Agama Hindu}

Dean Barlund menjabarkan komunikasi antar personal sebagai "perilaku orangorang pada pertemuan tatap muka dalam situasi sosial informal dan melakukan interaksi terfokus lewat pertukaran syarat verbal dan nonverbal yang saling berbalasan". Jadi bila ada proses komunikasi yang tidak menimbulkan pertukaran isyarat verbal dan nonverbal, maka kegiatan tersebut tidak bisa disebut proses komunikasi. Komunikasi antar personal merupakan pertemuan dari paling sedikit dua orang yang bertujuan untuk memberikan pesan dan informasi secara langsung dalam situasi sosial informal yang melakukan interaksi terfokus melalui pertukaran isyarat verbal dan nonverbal. Komunikasi antar personal merupakan proses pertukaran informasi yang dianggap paling efektif dan proseswnya dapat dilakukan dengan cara sangat sederhana. Selain efektif komunikasi antar personal merupakan proses pertukaran informasi yang dianggap penting dan menjadi keharusan bagi setiap insan, baik dalan organisasi formal maupun nonformal. Setiap orang 
senantiasa membutuhkan dan berusaha membuka serta menjalin komunikasi dengan orang lain. Adanya sejumlah kebutuhan di dalam setiap diri individu hanya dapat dipuaskan melalui kegiatan komunikasi antar sesamanya.

\section{Komunikasi efektif pada anak usia dini} dalam pengenalan ajaran Agama Hindu Berkomunikasi dengan anak usia dini berbeda dari berkomunikasi dengan remaja maupun orang dewasa. Pemikiran anak cenderung lebih Sederhana, konkret (nyata), penuh khayal, kreatif, ekspresif, aktif, dan selalu berkembang. Untuk itu Para Guru dan Orang tua harus dapat menyesuaikan cara berkomunikasinya dengan anakanak (bukan anak-anak yang harus menyesuaikan dengan Para Guru dan Orang tua). Dalam bahasa lain, kita menerapkan komunikasi demokratis atau yang saling menghargai. Untuk membuat anak usia dini merasa nyaman saat berkomunikasi dengan Para Guru dan Orang tua, upayakanlah menerapkan hal-hal berikut:

a. Dengarkan apa yang diceritakan anak dan pancing untuk lebih banyak bercerita. la senang sekali menceritakan pengalaman-pengalaman yang baru dilaluinya dan ia akan bersemangat bercerita, jika para Guru dan Orang tua mendengarkan dan tertarik dengan apa yang diceritakannya.

b. Saat anak sedang menceritakan sesuatu, fokuskan perhatian pada ceritanya. Hentikan sejenak kegiatan yang para Guru dan Orang tua lakukan, ajak ia mendekat dan dengarkan dengan saksama. Jika perlu, beri sedikit tanggapan.

c. Ulangi cerita anak untuk menyamakan pengertian, karena mungkin bahasa anak berbeda dengan bahasa kita, sehingga tidak terjadi kesalahpahaman dalam memahami cerita anak.

d. Bantu anak mengungkapkan perasaannya dengan bertanya. Jika anak masih bingung tentang apa yang dirasakannya, apa yang membuatnya sedih atau gembira, maka dengan meminta ia bercerita akan membuatnya merasa diperhatikan.

e. Bimbing anak untuk memutuskan sesuatu yang tepat. Jelaskan akibat apa yang akan terjadi jika ia mengambil suatu keputusan, jelaskan sebab dan akibat dari keputusan itu secara sederhana agar mudah dimengerti olehnya.

f. Emosi anak yang masih belum stabil membuat ia mudah marah. Tunggu sampai ia tenang, baru dekati dan tanyakan apa yang mengesalkan hatinya. Jangan sampai membuat anak merasa sedang diabaikan atau tak diacuhkan.

g. Saat berkomunikasi dengan anak usia dini, ibu dan ayah tak perlu malu, misalnya harus berperan sebagai badut di depan anak, jika dengan cara itu anak akan lebih bisa memahami dan mengerti apa yang para Guru dan Orang tua maksudkan.

Komunikasi dengan anak yang dijalin sejak dini dapat memudahkan dalam mendidik dan mengarahkan anak usia dini. Yang Boleh dan Tidak Boleh Dilakukan Para Guru dan Orang tua Ketika Berkomunikasi dengan Anak

I. Yang tidak boleh dilakukan:

A. 12 gaya berkomunikasi berikut ini:

1. Memerintah

2. Menyalahkan

3. Meremehkan

4. Menasehati

5. Membandingkan

6. Membohongi

7. Memberi julukan negative 
8. Menghibur

9. Mengancam

10. Mengkritik

11. Menyindir

12. Menyelidik

Bila salah satu gaya itu dilakukan, maka anak usia dini akan tidak percaya pada perasaannya sendiri dan Anak usia dini tidak percaya diri. Kemampuan anak usia dini menangkap pesan masih terbatas. Tidak memberi kesempatan pada anak usia dini untuk memahami pesan. Bila hal tersebut dilakukan, maka anak usia dini tidak memahami pesan. Terjadi banyak kesalahan dalam proses pengasuhan, akhirnya Para Guru dan Orang tua jadi sering marah.

II. Yang boleh dilakukan:

A. Membaca bahasa isyarat tubuh (perilaku anak). Karena bahasa tubuh atau perilaku anak lebih mudah dilihat dan tidak pernah berbohong. Bahasa tubuh lebih nyata dibandingkan dengan bahasa lisan. Bila hal tersebut tidak dilakukan, maka kita tidak akan memahami anak. Anak usia dini lebih mudah emosi/marah.

B. Mendengarkan ungkapan perasaan anak. Dengan kita mendengarkan ungkapan perasaan anak berarti mengurangi emosi anak dan merangsang kemampuan berbicara.

C. Mendengarkan aktif.

Untuk membangun anak dalam hubungan sosialnya dan kepercayaan dirinya. Caranyad engarkan dengan sungguh-sungguh sepenuh perasaan. Wajah ibu-ayah menghadap langsung ke wajah anak, dengan pandangan mata sejajar.

D. Menggunakan "pesan saya....". Untuk melatih anak memahami perasaan orang lain. Caranya: Ungkapkan perasaan (positif) ibu-ayah kepada anak.
Contoh, "Ibu khawatir kalau kamu berlari-larian seperti itu, nanti kamu bisa terjatuh, Nak. Pesan Ibu, berjalan pelan saja ya Nak" Atau, "Ayah sayang kamu, Nak. Karena itu Ayah sedih kalau kamu suka memukul temanmu, Pesan ayah, sayangi temanmu ya Nak. "

E. Menggunakan kata motivasi

Gunakan kata "ayo", "coba", "mari", "silakan" untuk menggantikan kata "jangan" dan "tidak". Catatlah berapa kali dalam sehari Para Guru dan Orang tua menggunakan kata "tidak", "sudah", "berhenti", "jangan", "tunggu", "ayah/ibu bilang apa". Gantilah katakata tersebut dengan kata-kata positif dalam komunikasi:

Untuk memberikan motivasi dan dukungan, kata "ayo", "coba", "mari", "silakan" dapat membantu anak usia dini mencoba melakukan. Sedangkan kata "jangan" dan "tidak boleh" kadang malah dapat mendorong anak melakukan perlawanan, penolakan atau ingin mencoba. Contoh kalimat larangan, "Jangan naik pohon, nanti jatuh!" Dapat diganti dengan kalimat ajakan, "Ayo, kita bermain di bawah pohon saja, pasti lebih menyenangkan." Untuk menggantikan kalimat larangan harus diberikan pilihan yang dapat dipilih anak. Misalnya, seorang anak bernama Ade, meloncatloncat di atas kursi, maka kalimat yang kita gunakan, misalnya, "Ade boleh duduk di atas kursi atau boleh meloncat di atas karpet ini."

F. Menggunakan kalimat dan katakata positif.

Mengajak dengan menggunakan kalimat positif dan melarang dengan alasan yang bisa dipahami anak. Contoh, anak mau naik pohon yang basah karena hujan.

Kalimat yang biasa digunakan adalah, "Kamu jangan naik pohon, nanti jatuh." Sebaiknya ganti dengan kalimat, "Nak, 
coba lihat, pohon ini licin karena hujan semalam, kamu bisa terpeleset dan jatuh kalau naik pohon ini." Atau, "Pohon ini licin karena hujan semalam, kamu bisa terpeleset dan jatuh kalau memanjatnya, jadi sebaiknya kamu tidak naik pohon ini." Anak berjalan dengan menyeret selimutnya.

Kalimat yang biasa digunakan, "Selimutnya jangan diseret-seret begitu, nanti jadi kotor." Gantilah dengan kalimat positif berikut, "Maaf, Nak, selimutnya sebaiknya tidak diseret-seret begitu, nanti jadi kotor." Atau, "Maaf, Nak, angkat selimutnya supaya tetap bersih."

G. Membiasakan mengucapkan kata "terima kasih", "permisi", "maaf" dan "minta

tolong" pada anak sesuai dengan kejadiannya. Contoh:

"Terima kasih ya, Nak, Bunda dibantu merapikan mainan."

"Permisi ya, Nak, Ibu ke dapur sebentar." "Maaf, Nak, kita bermainnya sudah cukup dulu, sekarang waktunya mandi."

"Nak, Ayah minta tolong, sampahnya dibuang di tempat sampah, ya."

H. Mengembangkan pertanyaan terbuka.

Untuk melatih berpikir kritis dan kecerdasan anak usia dini. Caranya:

- Ajari anak membedakan perbuatan baik dan buruk.

Contoh, ketika anak menonton film kartun Tom and Jerry, tanyakan kepadanya, "Nak, menurutmu, perbuatan Tom dan Jerry yang selalu berkelahi itu, baik apa tidak ya? Sebaiknya bagaimana, ya?" Ajari anak membedakan benar dan salah. Contoh, "Nak, sebaiknya kita membuang sampah di mana, ya?"

I. Menggunakan kata-kata yang benar.
Untuk melatih anak memiliki pengetahuan tentang tata bahasa yang benar, kita tidak dibenarkan mengikuti atau menirukan kata-kata anak yang masih belum jelas, atau pemenggalan kata yang tidak utuh. Contoh: kata "mam-mam" untuk "makan", "embin" atau "obin" untuk "mobil", dan sebagainya.

Jadi, kita harus mengucapkan kata dengan istilah yang sebenarnya dan jelas. Contoh, kita mau meminta anak usia dini menirukan kata "makan". Jangan katakan, "Nak, agar kamu jadi kuat dan sehat, kamu harus ma...." (mengharap anak melanjutnya dengan suku kata "kan"). Seharusnya kita mengatakan, "Nak, agar kamu jadi kuat dan sehat, kamu harus makan. Harus apa, Nak?", dengan harapan anak akan mengatakan "makan". Jadi, gunakan kata yang utuh.

J. Memberikan contoh perbuatan dari Para Guru dan Orang tua.

Apa yang dilihat anak akan dilakukan, karena anak lebih percaya pada apa yang dilihat daripada didengar. Jadi, sebaiknya Para Guru dan Orang tua memberikan contoh perbuatan secara langsung pada anak. Antara lain, Pembiasaan menggosok gigi saat anak telah tumbuh giginya. Ibu dan ayah menggosok gigi di dekat anak, anak diberikan sikat gigi yang sesuai dan dapat memotivasinya untuk mencoba, semisal sikat gigi dengan bentuk dan gambar-gambar lucu. Pembiasaan membuang sampah di tempat sampah. Para Guru dan Orang tua menunjukkan sambil berkata, "Kalau membuang sampah harus di tempat sampah." Para Guru dan Orang tua memberikan contoh merapikan mainan, lalu anak diminta melanjutkan sampai tuntas. Atau, Para Guru dan Orang tua mengajak dan anak merapikan mainan 
bersama-sama, "Nak, ayo kita simpan kembali mobil-mobilan ini di kotak mainannya." Para Guru dan Orang tua seringlah membaca buku, majalah, atau koran di dekat anak. Sediakan buku cerita bergambar yang sesuai dengan usia anak untuk merangsang anak tertarik dengan buku dan akhirnya jadi gemar membaca.

Pakar komunikasi lain, Joseph A Devito mengemukakan komunikasi sebagai transaksi. Transaksi yang dimaksudkannya bahwa komunikasi merupakan suatu proses dimana komponen-komponennya saling terkait dan bahwa para komunikatornya beraksi dan bereaksi sebagai suatu kesatuan dan keseluruhan. Dalam setiap proses transaksi, setiap elemen berkaitan secara integral dengan elemen lain (Suprapto, 2006 : 5). Agar apa yang disamapaikan oleh komunikator kepada komunikan mampu dipahami dengan baik oleh komunikan perlu terjalin sebuah komunikasi yang efektif. Dalam pembahasan ini khususnya komunikasi efektif pada anak usia dini dalam pengenalan agama Hindu di Taman Kanak-Kanak.

\section{Komunikasi Verbal}

Komunikasi Verbal adalah komunikasi yang mempergunakan katakata, lisan maupun tulisan. Komunikasi ini paling banyak dipergunakan dalam hubungan antar kehidupan. Melalui kata-kata, mengungkapkan perasaan, emosi, pemikiran gagasan atau maksud, menyampaikan fakta, data dan informasi serta menjelaskannya, saling perasaan dan pemikiran, saling berdebat dan bertengkar. Komunikasi verbal bahasa sangat memegang peran yang sangat penting (Harjana, 2003:22).
Menurut Mulyana dalam (Harahap, 2014 : 26) menyatakan; "bahasa dapat juga dianggap sebagai sistim kode etik verbal. Bahasa dapat didefinisikan sebagai seperangkat simbol dengan aturan untuk mengkombinasikan simbol-simbol yang digunakan dan dipahami suatu komunitas. Namun sebagai alat komunikasi bahasa juga memiliki keterbatasan. Keterbatasan bahasa itu meliputi: 1) keterbatasan jumlah kata yang tersedia untuk mewakili objek, 2) kata bersifat ambigu dan kontekstual, dan 3) kata-kata mengandung bias budaya".

\section{Komunikasi Nonverbal}

Komunikasi nonverbal adalah penyampaian pesan tanpa kata-kata dan komunikasi nonverbal memberikan arti pada komunikasi verbal. Yang termasuk komunikasi nonverbal adalah: 1) Ekspresi Wajah merupakan sumber yang kaya dengan komunikasi, karena ekspresi wajah cerminan suasana emosi seseorang. 2) Kontak mata, merupakan sinyal alamiah untuk berkomunikasi. Melalui kontak mata juga memberikan kesempatan pada orang lain untuk mengobservasi yang lainnya. 3) Sentuhan adalah bentuk komunikasi personall mengingat sentuhan lebih bersifat spontan dari pada komunikasi verbal. 4) Postur tubuh dan gaya berjalan.

Menurut Johnson dalam Harahap (2014 : 109) menyatakan, perilaku nonverbal memiliki karateristik sebagai berikut: 1) merupakan kebiasaan maka bersifat otomtis dan jarang disadari. 2) Berfungsi mengungkapkan perasaanperasaan yang sebenarnya, kendati demikian kata-kata seseorang dapat menyembunyikannya. 3) komunikasi nonverbal merupakan sarana utama 
untuk mengungkapkan emosi. Agar benar-benar memahami pembicaraan seseorang, maka bagian nonverbal dan komunikasinya harus sungguh-sungguh dicermati. 4) Memiliki makna yang berlainan pada bagaian lingkungan budaya yang berbeda. 5) memiliki makna yang berbeda dari orang ke orang atau pada orang yang sama namum berlainan waktu.

Dalam konsep Hindu, mendidik seorang anak dimulai semenjak dalam kandungan. Hal ini termuat dalam Semara Reka dan Angastya Prana. Untuk dapat mendidik anak agar menjadi seorang yang Suputra, maka terlebih dahulu orang tualah yang harus merubah dirinya menjadi orang tua yang baik. Karena itu dianjurkan dalam sastra agar seorang ibu mengandung setelah proses upacara perkawinan. Disamping menghindari pengaruh beban psikis jika hamil sebelum melangsungkan upacara perkawinan, setelah melalui upacara perkawinan maka Sanghyang Kama Ratih dalam diri orang tua telah disucikan sebelum bertemu dan menjadi benih dan lading harus dibersihkan dan disucikan terlebih dahulu untuk mendapatkan hasil yang baik. Mendidik anak semasih di dalam kandungan atau yang diistilahkan Prenatal, dimulai dari pembenahan pola fikir dan sikap kedua orang tua. Saat mengandung maka kedua orang tua sesungguhnya sedang beryoga untuk mampu mengekang dan menghindari segala sesuatu yang tidak baik agar tidak berpengaruh pada janin. Wanita hamil diharuskan untuk terhindar dari perasaan yang kuat, misalnya marah, sedih, terlalu bergembira, terlebih lagi sampai bertengkar saat hamil karena perasaan tersebut akan mempengaruhi perkembangan dan karakteristik si bayi. Masa-masa ngidam bagi wanita hamil merupakan seuah ujian bagi para calon ayah. Banyak para calon ayah yang sering tidak memperhatikan istri hamil yang sedang dalam masa ngidam, dan itu merupakan salah satu pendidikan yang salah. Karena sesungguhnya saat itu calon bayi sedang menguji keteguhan sang calon ayahuntuk membuktikan bahwa dia adalah seorang yang pantas dan bertanggung jawab untuk dijadikan orang tua. Jika sampai ada calon ayah yang mengabaikan istri pada saat hamil, maka akan lahir seorang anak yang berani kepada orang tua, hal ini seperti termuat dalam Lontar Semara Reka dan Angastya Prana. Masa kehamilan adalah masa yang penting untuk mendidik si calon bayi. Maka dari itu tidak diperbolehkan memarahi wanita hamil, menipu atau bahkan mengagetkan wanita hamil. Seperti termuat dalam tattwa cerita tentang Ida Bhatara Dewi Uma yang pada waktu beliau hamil sempat dikagetkan oleh gajah sehingga saat melahirkan maka lahirlah putera beliau sang Ganesha yang berkepala Gajah. Cerita ini sesungguhnya menjelaskan kepada kita bahwa seberapa pun beratnya kondisi, rasa emosi dan perasaan yang tidak baik lainnya, maka semua itu harus dikendalikan karena masa kehamilan adalah masa beryoga bagi kedua orang tua.

Setelah pendidikan dalam kandungan, maka ada pendidikan setelah bayi lahir atau yang diistilahkan Pascaanatal. Dalam konsep ajaran Hindu seorang anak yang baru lahir hingga berusia enam tahun tak ubahnya seperti seorang dewa maka perlakukanlah dia seperti seorang dewa. Tidak diperbolehkan melakukan kekerasan terhadap anak usia tersebut baik berupa kekerasan kata-kata maupun fisik. 
Pendidikan seorang anak dalam fase seperti dewa telah diterapkan oleh leluhur kita sejak lampau, oleh karena itu jika kita lihat implementasinya di masyarakat, misalnya tidak ada aka nada orang yang marah jika ada anak kecil mempermainkan kepala kakeknya, atau anak kecil bermain diatas bantal tempat tidur.

Ketika si anak sudah menginjak usia enam sampai dua belas tahun maka seorang anak tidak ubahnya seperti seorang raja, dia sudah mulai meminta ini dan itu. Sebisa mungkin orang tua harus menuruti, tentunya dalam batasbatas yang wajar. Jika anak agak nakal maka harus dinasehati dengan sabar dan dengan kasih saying seperti menasehati seorang raja, karena dalam masa ini seorang anak sedang mengembangkan kemampuan otaknya sehingga memiliki rasa ingin tahu yang sangat tinggi.

Saat anak sudah berusia dua belas tahun hingga tujuh belas tahun maka seorang anak harus mulai diajarkan disiplin. Seorang anak harus mulai diberi tugas dan tanggung jawab. Ajari anak untuk melakukan tugasnya dengan bertanggung jawab. Misalnya diberi tugas menyapu, mengepel, membanten dan sebaginya. Dalam masa ini orang tua harus bisa menerapkan ajaran Catur Naya Sandhi yaitu sama, beda, dhana dan danda. Kapan orang tua harus berposisi sama sejajar dengan anak (sama), kapan harus memposisikan diri berbeda dengan anak yaitu sebagai seorang guru dan pendidik sekaligus pengawas (beda), kapan saatnya orang tua harus memberikan hadiah kepada anak sebagai motivasi bagi si anak (dhana) dan kapan saatnya kita memberikan hukuman kepada anak(danda) harus dipahami saat-saat yang tepat untuk menjalankan fungsi di atas.

Setelah anak berusia diatas tujuh belas tahun maka orang tua harus bisa memposisikan diri sebagai seorang sahabat bagi anak-anaknya. Saat dewasa seorang anak sudah mulai mengikuti kata hatinya, sehingga orang tua harus mampu memahami kondisi tersebut. Dengan bersikap seperti sahabat bagi si anak, maka aka nada keterbukaan antara orang tua dan anak sehingga orang tua akan lebih mudah mengontrol dan menasehati si anak. Sudah tidak lagi dalam usia tersebut untuk memarahi dan mengekang anak seperti memarahi anak kecil. Hal tersebut justru akan membuat anak semakin jauh dan tertutup dengan orang tua.

\section{Dampak pengenalan ajaran Agama Hindu pada anak usia dini}

1) Dampak internal

Dampak Internal merupakan dampak yang terjadi dalam diri individu khususnya anak-anak di Taman KanakKanak dalam rangka menerima pengetahun yang diproses dalam diri. Hal ini dapat dilihat dari perubahan sikap dan tingkah laku anak setiap harinya.

Menurut Momas dalam Goldburg dan Larson, (1985:56), ada 3 unsur dalam suatu kelompok yaitu kegiatan interaksi dan perasaan terdiri dari tindakantindakan anggota kelompok yang berhubungan dengan tugas kelompok. Dalam melakukan tindakan-tindakan tersebut mereka terlibat dalam suatu interaksi yaitu mereka memperlihatkan saling ketergantungan dan saling menanggapi dalam bertingkahlaku. Meskipun definisi Hotmans tentang elemen ini tidak hanya mencakup aspek komunikasi tetapi sebagaian besar 
interaksi tersebut melibaTaman KanakKanakan komunikasi anatar pribadi.

Dampak internal dari pendikan agama Hindu pada anak usia dini di Taman Kanak-Kanak adalah mereka menjadi lebih rajin bersembahyang dan dapat melakukan Mantram Gayatri sendiri, yang dulunya mereka tidak dapat melakukan sendiri". Hal ini memperlihatkan di Taman Kanak-Kanak seorang anak di dalam dirinya memiliki pemahaman terhadap pengenalan yang diberikan sehingga mau melakukannya. Adanya komunikasi efektif akan mempengaruhi eksternal dan internal setiap individu di Taman Kanak-Kanak . Sehingga hal ini akan memunculkan dampak eksternal dan internal yang pada masing-masing individu. Dampak yang dimunculkan bereda-beda tergantung tingkat pemahaman serta pengolahan informasi terhadap pelajaran khususnya pelajaran agama yang diberikan. Sehingga dalam proses interaksi saat pelajaran di kelas dan interaksi saat bermain bersama ada anak-anak yang aktif dan kreatif tetapi ada juga anak anak yang pendiam bahkan tidak mau berbuat apapun.

2) Dampak Eksternal dari Pengenalan Agama Hindu di Taman Kanak-Kanak

Dampak eksternal adalah hasil dari pengolahan proses pengetahuan di dalam diri setiap individu yang dimunculkan melalui tindakan. Secara teoritis sistem internal tumbuh dari sistemeksternal tetapi kedua-duanya berlangsung secara bersamaan dalam kelompok. Kemampuan eksternal berhubungan dengan kepekaan seseorang untuk berinteraksi dengan orang lain atau kelompok. Anak usia dini mengalami kesulitan menerima pendapat orang lain karena anak usia dini bersifat egosentrisme, dalam kelompoknya anak-anak saling berbicara tanpa mengharapkan saling mendengar atau saling menjawab.

\section{PENUTUP}

Komunikasi antar personal merupakan proses pertukaran informasi yang dianggap paling efektif dan proseswnya dapat dilakukan dengan cara sangat sederhana. Selain efektif komunikasi antar personal merupakan proses pertukaran informasi yang dianggap penting dan menjadi keharusan bagi setiap insan, baik dalan organisasi formal maupun nonformal. pengenalan ajaran agama Hindu pada anak usia dini di Taman Kanak-Kanak membutuhkan komunikasi antar personal untuk memberikan pemahaman dan pertukaran informasi baik antar siswa, antar siswa dan guru, guru dengan guru, siswa dan orang tua maupun antar orang tua siswa dan guru.

Komunikasi efektif sangat berperan dalam meningkatkan pemahaman dan pengertian dalam pemahaman ajaran Agama Hindu. Komunikasi efektif memberikan gambaran terhadap tujuan dan hasil yang hendak dicapai oleh sekolah maupaun pengajaran guru di kelas. Komunikasi efektif dapat dibagi menjadi dua, yaitu komunikasi verbal dan komunikasi nonverbal.

Ada dua dampak yang dipengaruhi dari pengenalan ajaran Agama Hindu pada anak usia dini di Taman Kanak-Kanak . Dampak ini dilihat dari segi Eksternal dan Internal siswa. Dampak Internal merupakan dampak yang terjadi dalam diri individu khususnya anak-anak di Taman Kanak-Kanak dalam rangka menerima pengetahun yang diproses dalam diri. Dampak eksternal adalah hasil dari pengolahan proses 
pengetahuan di dalam diri setiap individu yang dimunculkan melalui tindakan.

\section{DAFTAR PUSTAKA}

Ahmad,Djauzak, 1995/1996. Himpunan Peraturan tentang Sekolah Dasar, Jakarta.

Adi, I Gusti Made. 2007. Efektifitas Komunikasi Sosial Dalam Melestarikan Subak Sebagai Warisan Budaya di Subak Uma Mambal ( Skripsi). Denpasar Universitas Dwijendra.

Anna Poedjiadi, 2007. Filsafat IImu, Jakarta Universitas Terbuka.

Bungin, Burhan, 2006. Metodelogi Penelitian Kualitatif, Jakarta : PT. Raja Grafindo.

Gullo, W., 2002. Metode Penelitian, Jakarta : PT. Gramedia Widiasarana Indonesia.

Harahap, Edi. 2014. Komunikasi Antar Pribadi, Jakarta : PT Raja Grafindo Persada

Iqbal, Hasan, 2002, Pokok-Pokok Materi Metodelogi Penelitian dan Aplikasinya, Jakarta : Ghalia Indonesia.

Koentjaraningrat, 1958. Kebudayaan Indonesia.Jakarta : Balai Pustaka.

Moleong, 2004. Metodelogi Penelitian Kualitatif. Bandung : Remaja Rosdakarya.

Nurlaila, N.Q Mei Tientje, 2004. Pendidikan Anak usia dini Untuk Mengembangkan Multipel Intelegensi. Dharma Graha Group.

Shadily, Hasan., 1984. Ensiklopedi. Yogyakarta : Yayasan Kanisius.

Soegeng Santoso, 2004. Pendidikan Anak usia dini. Jakarta : Citra Pendidikan Indonesia.

Suprapto, Tommy. Pengantar Teori Komunikasi. Cetakan Ke-1.
Yogyakarta: Media Pressindo, 2006.

Syaiful, Rohim., 2009. Teori Komunikasi Perspektif, Ragam, dan Aplikasi. Jakarta : Rineka Cipta.

Winda Gunarti, 2008. Metode Pengembangan Perilaku Dan Kemampuan Dasar Anak usia dini, Jakarta : Universitas Terbuka. 